\title{
No SMAD4 hypermethylation in colorectal cancer
}

\author{
S Roth, ${ }^{1}$ P Laiho, ${ }^{1}$ R Salovaara, ${ }^{1,2}$ V Launonen ${ }^{1}$ and LA Aaltonen ${ }^{1}$ \\ ${ }^{1}$ Department of Medical Genetics, Haartman Institute, University of Helsinki, Finland; ${ }^{2}$ Department of Pathology, Haartman Institute, University of Helsinki, \\ Finland
}

\begin{abstract}
Summary The chromosome region $18 \mathrm{q} 21$ is frequently deleted in colorectal cancers. Three candidate tumour suppressor genes, $D C C$, SMAD4 and SMAD2, map to this region. The SMAD4(DPC4) gene was recently identified as a candidate pancreatic cancer suppressor gene. It is also a gene for juvenile polyposis tumour predisposition syndrome. Somatic SMAD4 mutations have been detected in some colorectal carcinomas. However, the frequency of these mutations is relatively low, and whether SMAD4 plays a key role in colorectal tumorigenesis is still unclear. In addition to loss of chromosomal material and intragenic mutations there is a third mechanism, DNA methylation, which may have an important role in gene inactivation. In the present study, we examined whether promoter hypermethylation could be a mechanism for SMAD4 inactivation. In total, 42 colorectal tumours were selected for the methylation analysis and no evidence of promoter hypermethylation was found. Our result suggests that hypermethylation of the SMAD4 promoter region is not a frequent event in colorectal tumorigenesis. (c) 2000 Cancer Research Campaign
\end{abstract}

Keywords: SMAD4; colorectal cancer; hypermethylation; promoter

Colorectal carcinogenesis is a multistep process, and tumour progression is promoted by a series of genetic changes that involve activation of oncogenes and inactivation of tumour suppressor genes (Vogelstein et al, 1988; Kinzler and Vogelstein, 1998). The prominent role of some tumour suppressor genes such as $A P C$ (5q) and $p 53(17 \mathrm{p})$ has been widely recognized. Several other tumour suppressor genes have been suggested to exist e.g. on chromosome bands $1 p, 8 p, 18 q$ and $22 q$, and inactivation of these genes may play a role in colorectal carcinogenesis (Vogelstein et al, 1988; Miyaki et al, 1999).

Previous studies have demonstrated that at least one copy of chromosome $18 \mathrm{q}$ is lost in over 70 percent of sporadic colorectal cancers (Vogelstein et al, 1988; Ried et al, 1996; Meijer et al, 1998; Korn et al, 1999). Three candidate tumour suppressor genes, $D C C, S M A D 4$ and SMAD2, map to this region. Loss of expression of $D C C$ has been reported in advanced colorectal carcinomas, but mutations in the coding region seem to be rare, and the position of $D C C$ as a candidate tumour suppressor is still not clear (Fearon et al, 1990; Kikuchi-Yanoshita et al, 1992; Cho et al, 1994). SMAD4, originally named as $D P C 4$, is frequently deleted in pancreatic cancers (Hahn et al, 1996). Loss of the SMAD4 region relatively rarely occurs in other types of tumours. An important exception is colorectal cancer, in which there is good evidence for allelic loss at this locus (Takagi et al, 1996; Thiagalingham et al, 1996). Mutations of SMAD4 and SMAD2 genes have been detected in some colorectal carcinomas, but the frequency of these mutations is relatively low (Eppert et al, 1996; Takagi et al, 1996; Thiagalingham et al, 1996; MacGrogan et al, 1997).

Knudson's hypothesis that two hits are required for the full inactivation of a tumour suppressor gene has been shown to be correct

Received 25 January 2000

Revised 20 April 2000

Accepted 15 June 2000

Correspondence to: LA Aaltonen in many human cancers (Jones and Laird, 1999). Traditionally, it has been thought that intragenic mutations and loss of chromosomal material inactivate tumour suppressor genes. However, the fact that methylation of $\mathrm{CpG}$ islands located in the promoters of genes can cause transcriptional silencing, has led to the suggestion that hypermethylation of tumour suppressor gene promoters is one of the mechanisms promoting malignant transformation (Jones and Laird, 1999). The pattern characterized by methylation in tumour tissue and lack of methylation in normal mucosa is consistent with the $\mathrm{CpG}$ island methylator phenotype (CIMP), typical for the colorectal cancers displaying microsatellite instability (MSI) (Toyota et al, 1999). On the other hand, the promoter hypermethylation in normal mucosa and lack of methylation in tumour tissue have been reported in sporadic microsatellite stable (MSS) colorectal cancers (Kuismanen et al, 1999). Recently, the involvement of SMAD4 in sporadic colorectal neoplasia was studied by immunohistochemistry (Salovaara et al, submitted) and it was shown that SMAD4 expression was considerably reduced in unselected colorectal carcinomas. This prompted us to examine whether promoter hypermethylation plays a role in SMAD4 inactivation.

One candidate region for the SMAD4 promoter was first reported by Minami et al (1998). They cloned a 1.4-kb fragment of the SMAD4 5'-flanking region from phage library by using the first coding exon's sequence as a primer. This SMAD4 promoter lacks typical TATA boxes and CpG island, but contains some TATA-like structures (TAAAAT) as well as some binding sites for transcription factors (Minami et al, 1998). Another candidate sequence for the SMAD4 promoter has been characterized by Hagiwara et al (submitted). This region locates upstream from the previously reported coding exons and it includes a new non-coding exon (exon 1), $\mathrm{CpG}$ island as well as TATAA and CCAAT boxes and consensus SP1 binding site (GGGCGGG).

The aim of this study was to confirm the low frequency of SMAD4 mutations in colorectal cancer and to evaluate the role of promoter region alterations in SMAD4 inactivation. 
Table 1 List of samples included into SMAD4 methylation analysis. Tumour stages are shown as Dukes' stages $(A=$ tumour limited to mucosa and submucosa; $B$ = tumour penetrating the muscle wall; $C=$ metastases to regional lymph nodes; $D=$ distant metastases). The proportion of tumour tissue is shown as percentage. Among 42 sample pairs, 26 tumours were previously shown to be MSI (Aaltonen et al, 1998'; Salovaara et al, 2000). Either normal mucosa (NM) or blood (B) was used as a source of normal tissue for DNA extraction. The presence of SMAD4 protein has been previously analysed from 18 out of 42 tumour samples (Salovaara et al, submitted), and 5 of them were SMAD4 negative. An asterisk marks the 9 samples also included into mutation analysis.

\begin{tabular}{|c|c|c|c|c|c|}
\hline Sample No. & Dukes' stage & Tumour $\%$ & MSS/ (ref) MSI & Origin of normal DNA & $\begin{array}{l}\text { Immunostaining } \\
\text { by Salovaara et al }\end{array}$ \\
\hline $\mathrm{C} 104^{*}$ & $\mathrm{~B}$ & 80 & $\mathrm{MSI}^{1}$ & NM & Not included \\
\hline $\mathrm{C} 144^{*}$ & $\mathrm{~B}$ & 90 & $\mathrm{MSI}^{1}$ & NM & Not included \\
\hline $\mathrm{C} 145^{*}$ & $\mathrm{C}$ & 70 & $\mathrm{MSI}^{1}$ & NM & $\mathrm{Ca}+$ \\
\hline $\mathrm{C} 171^{*}$ & $\mathrm{~B}$ & 75 & $\mathrm{MSI}^{1}$ & $\mathrm{~B}$ & $\mathrm{Ca}+$ \\
\hline $\mathrm{C} 287$ & $A$ & 75 & $\mathrm{MSI}^{1}$ & $\mathrm{~B}$ & $\mathrm{Ca}+$ \\
\hline C406* & $\mathrm{C}$ & 85 & $\mathrm{MSI}^{1}$ & NM & Not included \\
\hline C484 & $\mathrm{D}$ & 80 & $\mathrm{MSI}^{1}$ & NM & $\mathrm{Ca}+$ \\
\hline C500 & $\mathrm{B}$ & 75 & $\mathrm{MSI}^{1}$ & NM & $\mathrm{Ca}+$ \\
\hline C521 & $\mathrm{D}$ & 70 & $\mathrm{MSI}^{1}$ & NM & $\mathrm{Ca}+$ \\
\hline C526 & $\mathrm{C}$ & 90 & MSS $^{1}$ & NM & Not included \\
\hline C532 & $\mathrm{B}$ & 75 & $\mathrm{MSI}^{1}$ & NM & $\mathrm{Ca}+$ \\
\hline C543 & $?$ & 90 & $\mathrm{MSI}^{1}$ & NM & Not included \\
\hline C549* & A & 80 & $\mathrm{MSI}^{1}$ & NM & Not included \\
\hline C567 & $\mathrm{B}$ & 85 & $\mathrm{MSI}^{1}$ & NM & Not included \\
\hline C568 & $\mathrm{B}$ & 70 & $\mathrm{MSI}^{1}$ & NM & $\mathrm{Ca}+$ \\
\hline C578 & B & 85 & $\mathrm{MSI}^{1}$ & NM & $\mathrm{Ca}+$ \\
\hline C732 & $A$ & 60 & $\mathrm{MSI}^{2}$ & NM & Not included \\
\hline C733 & $\mathrm{C}$ & 90 & MSS $^{2}$ & NM & Not included \\
\hline C744 & $\mathrm{B}$ & 70 & $\mathrm{MSI}^{2}$ & $B$ & $\mathrm{Ca}+$ \\
\hline C758 & B & 85 & $\mathrm{MSI}^{2}$ & B & Not included \\
\hline C768 & $\mathrm{C}$ & 55 & $\mathrm{MSI}^{2}$ & NM & Not included \\
\hline C777 & B & 65 & $\mathrm{MSI}^{2}$ & NM & Not included \\
\hline C778 & $\mathrm{C}$ & 90 & $\mathrm{MSI}^{2}$ & NM & Not included \\
\hline C789 & $A$ & 50 & $\mathrm{MSI}^{2}$ & NM & Not included \\
\hline $\mathrm{C} 800$ & B & 70 & $\mathrm{MSI}^{2}$ & NM & Not included \\
\hline $\mathrm{C} 813$ & B & 90 & MSS $^{2}$ & NM & Not included \\
\hline C844 & B & 70 & $\mathrm{MSI}^{2}$ & NM & Not included \\
\hline C846 & $\mathrm{B}$ & 90 & $\mathrm{MSS}^{2}$ & NM & Not included \\
\hline C883 & B & 85 & $\mathrm{MSI}^{2}$ & B & $\mathrm{Ca}+$ \\
\hline C941 & $\mathrm{B}$ & 75 & $\mathrm{MSI}^{2}$ & NM & Not included \\
\hline C961 & $\mathrm{B}$ & 95 & MSS $^{2}$ & B & $\mathrm{Ca}-$ \\
\hline C962 & $\mathrm{C}$ & 70 & MSS $^{2}$ & B & Not included \\
\hline C964 & $\mathrm{B}$ & 75 & MSS $^{2}$ & B & Not included \\
\hline C978* & $\mathrm{C}$ & 60 & $\mathrm{MSS}^{2}$ & B & $\mathrm{Ca}-$ \\
\hline C982 & $\mathrm{C}$ & 60 & $\mathrm{MSS}^{2}$ & B & $\mathrm{Ca}-$ \\
\hline $\mathrm{C} 984^{*}$ & B & 60 & MSS $^{2}$ & B & $\mathrm{Ca}+$ \\
\hline C986 & $\mathrm{C}$ & 55 & MSS $^{2}$ & B & $\mathrm{Ca}-$ \\
\hline C988 & $\mathrm{C}$ & 50 & MSS $^{2}$ & B & $\mathrm{Ca}-$ \\
\hline C989 & $\mathrm{C}$ & 65 & MSS $^{2}$ & B & $\mathrm{Ca}+$ \\
\hline C1036 & $\mathrm{C}$ & 90 & MSS $^{2}$ & NM & Not included \\
\hline C1051* & $\mathrm{D}$ & 55 & $\mathrm{MSS}^{2}$ & B & Not included \\
\hline C1058 & $\mathrm{B}$ & 85 & MSS $^{2}$ & NM & Not included \\
\hline
\end{tabular}

\section{MATERIALS AND METHODS}

\section{Patients and tissue preparations}

Over one thousand fresh-frozen colorectal adenocarcinoma specimens were collected in the Department of Medical Genetics, Haartaman Institute, University of Helsinki between May 1994 and June 1998 (Aaltonen et al, 1998; Salovaara et al, 2000). To document the proportion of tumour tissue, all specimens had been examined histologically. Either normal mucosa or blood was used as a source of normal tissue for DNA extraction. The MSI status of the tumours had been determined previously (Aaltonen et al, 1998; Salovaara et al, 2000). Samples included in the present study are listed in Tables 1 and 2. The proportion of tumour tissue, stage of cancers (as Dukes' stages), MSI status and source of normal tissue
DNA are also presented. 24 out of 55 colorectal tumours included into this study have been previously analysed by immunohistochemistry for the presence of SMAD4 protein and the SMAD4 expression was below detection level in seven of them (Salovaara et al, submitted). The antibody used for immunostaining was monoclonal antibody to SMAD4 (B-8, Santa Cruz-7966), which has been previously reported to function well also on paraffin embedded tissue sections (Wilentz et al, 2000).

\section{SMAD4 PROMOTER METHYLATION}

The methylation status of the SMAD4 promoter was studied in 26 MSI and 16 MSS colorectal cancers (CRC). The fragment selected for this analysis was a CG-rich region characterized by Hagiwara 
Table 2 Tumour samples included into SMAD4 mutation screening. Tumour stages are shown as Dukes' stages. The proportion of tumour tissue is presented as percentage. Among 22 tumours, 15 were MSI, seven being MSS. The MSI/MSS status has been reported previously by Aaltonen et al (1998) ${ }^{1}$ and Salovaara et al $(2000)^{2}$. 10 out of 22 tumours have been previously analysed by SMAD immunostaining (Salovaara et al, submitted)

\begin{tabular}{|c|c|c|c|c|}
\hline Sample No. & Dukes' stage & Tumour \% & MSS/ (ref) MSI & $\begin{array}{l}\text { Immunostaining } \\
\text { by Salovaara et al }\end{array}$ \\
\hline C11 & $\mathrm{B}$ & 80 & $\mathrm{MSI}^{1}$ & $\mathrm{Ca}-$ \\
\hline C18 & $A$ & 90 & $\mathrm{MSI}^{1}$ & $\mathrm{Ca}+$ \\
\hline C43 & $A$ & 70 & $\mathrm{MSI}^{1}$ & Not included \\
\hline C54 & $\mathrm{D}$ & 60 & $\mathrm{MSI}^{1}$ & Not included \\
\hline C64 & $A$ & 70 & $\mathrm{MSI}^{1}$ & $\mathrm{Ca}+$ \\
\hline C104 & B & 80 & $\mathrm{MSI}^{1}$ & Not included \\
\hline C136 & B & 75 & $\mathrm{MSI}^{1}$ & $\mathrm{Ca}+$ \\
\hline C144 & B & 90 & $\mathrm{MSI}^{1}$ & $\mathrm{Ca}+$ \\
\hline C145 & C & 70 & $\mathrm{MSI}^{1}$ & $\mathrm{Ca}+$ \\
\hline C171 & B & 75 & $\mathrm{MSI}^{1}$ & $\mathrm{Ca}+$ \\
\hline C204 & B & 70 & $\mathrm{MSI}^{1}$ & Not included \\
\hline C239 & $B$ & 90 & $\mathrm{MSI}^{1}$ & Not included \\
\hline C331 & B & 90 & $\mathrm{MSI}^{1}$ & Not included \\
\hline C406 & $\mathrm{C}$ & 85 & $\mathrm{MSI}^{1}$ & Not included \\
\hline C549 & A & 80 & $\mathrm{MSI}^{1}$ & Not included \\
\hline $\mathrm{C} 977$ & $B$ & 65 & MSS $^{2}$ & $\mathrm{Ca}-$ \\
\hline C978 & $\mathrm{C}$ & 60 & MSS $^{2}$ & $\mathrm{Ca}-$ \\
\hline C983 & D & 70 & MSS $^{2}$ & Not included \\
\hline C984 & B & 60 & $\mathrm{MSS}^{2}$ & $\mathrm{Ca}+$ \\
\hline C1051 & $\mathrm{D}$ & 55 & $\mathrm{MSS}^{2}$ & Not included \\
\hline C1083 & $\mathrm{D}$ & 75 & $\mathrm{MSS}^{2}$ & Not included \\
\hline C1088 & B & 75 & $\mathrm{MSS}^{2}$ & Not included \\
\hline
\end{tabular}

et al (submitted), including the non-coding exon 1 (Figure 1). To determine whether this region was hypermethylated, a PCR-based HpaII and MspI restriction enzyme assay was used. This assay is based on the ability of the HpaII restriction enzyme to distinguish $\mathrm{CpG}$ sites that are methylated versus those that are nonmethylated. If the restriction sites are methylated, the methylation-sensitive HpaII can not cleave the DNA while MspI, which is the methylation-insensitive isoschizomer of HpaII, is capable to cleave. After digestion with these enzymes, SMAD4 primers flanking the HpaII/MspI site are used to test the HpaII and MspI treated DNA for PCR amplification. PCR product should be detected only when the original target DNA contains methylated HpaII restriction sites.

Both tumour and normal DNA were digested and the reactions contained either no enzyme, 25 units of HpaII, or 20 units of MspI for $16 \mathrm{~h}$ at $37^{\circ} \mathrm{C}$. To analyse cleavage of the SMAD4 promoter region, $12.5 \mathrm{ng}$ of DNA from each digest was analysed by PCR in $25 \mu 1$ reactions containing $1 \times \mathrm{PCR}$ reaction buffer $(\mathrm{PE} / \mathrm{ABI}), 100$ $\mu \mathrm{M}$ of each dNTP (Finnzymes), $1.5 \mathrm{mM}$ of $\mathrm{MgCl}_{2}, 1$ unit of AmpliTaqGOLD polymerase (PE/ABI), $10 \%$ of DMSO and $0.4 \mu \mathrm{M}$ of each primer. Primers were designed (Primer3) to amplify $408 \mathrm{bp}$ fragment of the SMAD4 promoter (Hagiwara et al, submitted) containing six HpaII/MspI restriction sites (Figure 1) and the primer sequences were: forward: 5'-CAAGTTGGCAGCAACAACAC; and reverse: 5'-ACATGGCGCGGTTACCT. PCR was performed for one cycle of $95^{\circ} \mathrm{C}$ for $10 \mathrm{~min}$ followed by 40 cycles of $95^{\circ} \mathrm{C}$ for $30 \mathrm{~s}, 60^{\circ} \mathrm{C}$ for $45 \mathrm{~s}$, and $72^{\circ} \mathrm{C}$ for $45 \mathrm{~s}$, followed by one cycle of $72^{\circ} \mathrm{C}$ for $10 \mathrm{~min}$. The resulting PCR products were analysed by agarose gel electrophoresis ( $3 \%$ agarose gel).

\section{Mutation analysis of SMAD4}

SMAD4 mutations were analysed among 15 MSI and seven MSS tumours from patients with $\mathrm{CRC}$, nine of those being same as in
1001 gecaaacct gaaattacce ggatgtggtc cccgcgegcg catgctcagt 1051 ggcttctcga caaattggca qcaacaacac ggccctggtc gtcgtcgccg 1101 ctgcggtaac ggagcggttt gggtggcgga gcetgcgttc gcgecttccc 1151 getctcetca ggaggccett cetgctetcc cetaggctcc gcggccgcc 1201 aggggtggg agcgghtgag gggagccagg cgc 1251 ccgccgcagg geggeccggg agctcgagge ggtecggccc gegcgggca 1301 cggcgcggcg ctgaggaggg gcggcetgge cgggacgcct cggggcggg

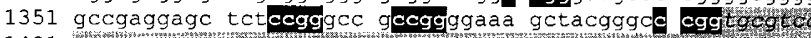

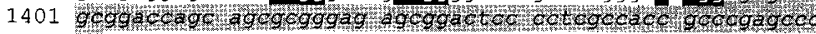

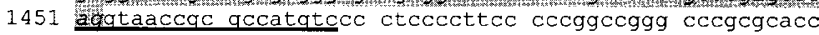
1501 ccgcetgtgg cttccccgcc ccggggcggg ctcccgacga cggcggcgge 1551 ggcggcggcg gctgggagcg cgcggaatcc tctgggaggg cgaccgcggc 1601 ggcetgacga gccgggccgg gcgggccggc tgaatgccgg gcggcggtgc 1651 ctcgcgtccc tcgggccccc agctcegctt gcagctcgtg ggagaatcaa

Figure $1 S M A D 4$ promoter region studied for methylation. The primers designed for this analysis are underlined. ccgg indicates all Hpall/Mspl restriction sites in this region. Grey shading depicts the noncoding exon 1

methylation analysis. These tumours were unselected regarding Dukes' stages A and B (4 tumours of stage A, 11 of stage B, 3 of stage $\mathrm{C}$, and 4 of stage $\mathrm{D}$, see Table 2). SMAD4 was amplified from genomic DNA by using previously published primers (Roth et al, 1999; Zhou et al, 1999). The PCR-reactions were carried out in $50 \mu \mathrm{l}$ reaction volume including $100 \mathrm{ng}$ genomic DNA, $1 \times$ PCR reaction buffer (Perkin Elmer Applied Biosystems Division), $200 \mu \mathrm{M}$ of each dNTP (Finnzymes), $0.8 \mu \mathrm{M}$ of each primer, and 2 units of AmpliTaqGOLD polymerase (PE/ABI). The $\mathrm{MgCl}_{2}$ concentration was $1.5 \mathrm{mM}$ in all reactions except for untranslated fragment, where the magnesium concentration was $2.5 \mathrm{mM}$. The following PCR cycles were used for amplification: exons 1, 2, and $11-10 \mathrm{~min}$ at $95^{\circ} \mathrm{C}, 40$ cycles of $45 \mathrm{~s}$ at $95^{\circ} \mathrm{C}, 45 \mathrm{~s}$ at $57^{\circ} \mathrm{C}, 1 \mathrm{~min}$ at $72^{\circ} \mathrm{C}$; for exons 3,5 , and $6-10 \mathrm{~min}$ at $95^{\circ} \mathrm{C}, 40$ cycles of $45 \mathrm{~s}$ at $95^{\circ} \mathrm{C}, 45 \mathrm{~s}$ at $58^{\circ} \mathrm{C}, 1 \mathrm{~min}$ at $72^{\circ} \mathrm{C}$; for exons $4,7,8,9$, and $10-10$ min at $95^{\circ} \mathrm{C}, 40$ cycles of $45 \mathrm{~s}$ at $95^{\circ} \mathrm{C}, 45 \mathrm{~s}$ at $56^{\circ} \mathrm{C}, 1 \mathrm{~min}$ at $72^{\circ} \mathrm{C}$; for $5^{\prime}$-untranslated fragment $-10 \mathrm{~min}$ at $95^{\circ} \mathrm{C}, 40$ cycles of $1 \mathrm{~min}$ at $95^{\circ} \mathrm{C}, 1 \mathrm{~min}$ at $56^{\circ} \mathrm{C}, 1 \mathrm{~min} 30 \mathrm{~s}$ at $72^{\circ} \mathrm{C}$. Final extension $10 \mathrm{~min}$ at $72^{\circ} \mathrm{C}$ was used for all fragments. After PCR, $5 \mu 1$ of the 
PCR product was run in a 3\% agarose (NuSieve) gel to verify the specificity of the PCR reaction. The rest of the PCR product was purified using QIAquick PCR purification kit (QIAGEN). Direct sequencing of the PCR products was performed using the $\mathrm{ABI}$ PRISM Dye Terminator or ABI PRISM dRhodamine cycle sequencing kits (PE/ABI). Cycle sequencing products were electrophoresed on 6\% Long Ranger gels (FMC Bioproducts) and analysed on an Applied Biosystems model 373A or 377 DNA sequencer $(\mathrm{PE} / \mathrm{ABI})$.

\section{Restriction enzyme digestion}

To screen for the presence of a base substitution in exon 2 in control individuals, restriction enzyme digestion was performed. NsiI (New England BioLabs) digestion was used to detect the G to A change at codon 118. NsiI cuts the PCR fragment (530 bp), which contains the base substitution into two fragments (264 bp and $266 \mathrm{bp}$ by size) whereas the wild-type fragment lacks the restriction site and is not digested. The PCR was performed as described above (SMAD4 mutation analysis, exon 2). The digestion was performed in $1 \times$ NEBuffer (New England BioLabs) at $37^{\circ} \mathrm{C}$ overnight. After digestion, the PCR products were electrophoresed through $3 \%$ agarose gel.

\section{RESULTS}

\section{SMAD4 promoter methylation}

In this study, the methylation status of the SMAD4 promoter was analysed using HpaII and MspI digestion. Using this assay, we examined the methylation status for SMAD4 promoter region in a group of 26 MSI and 16 MSS colorectal tumours (Table 1). The amplified sequence contained altogether $55 \mathrm{CpG}$ dinucleotides of which the methylation status for six CCGG sites was possible to determine by restriction (Figure 1). PCR amplification was not detected from any of HpaII digested DNA, suggesting that the SMAD4 promoter is unmethylated in all cases studied. The nondigested tumour and normal DNA showed amplification in all samples, demonstrating the efficiency of PCR reaction (Figure 2).

\section{SMAD4 mutation analysis}

Twenty-two primary colon cancers were analysed for mutations of all exons of SMAD4 by genomic sequencing (Table 2). Also part of the SMAD4 5'-untranslated region (331 bp fragment downstream from the transcription start site) published by Minami et al (1998) was included in mutation screening. The only change detected was $\mathrm{G}$ to $\mathrm{A}$ transition at the third position for codon 118 (exon 2). This silent change was present in one tumour sample (C11) and also in corresponding normal DNA. We analysed the frequency of this variant among 84 Finnish cancer free control individuals by restriction enzyme digestion (Nsil), and the change was found in one.

\section{DISCUSSION}

Loss of heterozygosity ( $\mathrm{LOH})$ on chromosome $18 \mathrm{q}$ is frequently detected during the progression of colorectal carcinomas. This suggests the presence of a tumour suppressor gene or genes at this region. Since identification of SMAD4/DPC4, mutation analyses of this gene have been carried out in many cancer types. However,

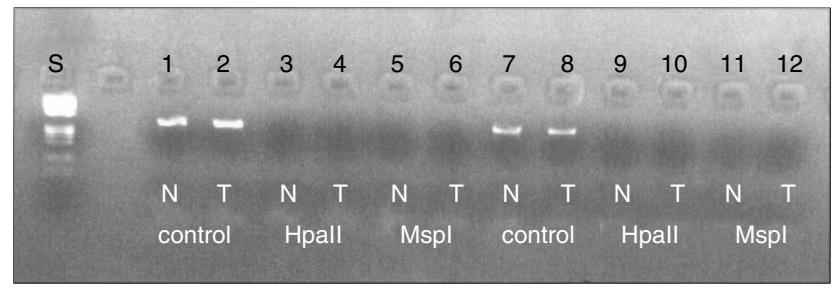

Figure 2 Methylation analysis of $\mathrm{CpG}$ islands of $S M A D 4$ promoter in two colorectal cancer samples (C789, lanes 1-6 and C800, lanes 7-12). Lanes 1, 2, 7 and 8: PCR product from nondigested normal $(\mathrm{N})$ and tumour (T) DNA. Lanes 3, 4, 9 and 10: lack of PCR product from Hpall digested normal and tumour DNA. Lanes 5, 6, 11 and 12: lack of PCR product from Msp/ digested normal and tumour DNA

a relatively low frequency of mutations $(<10 \%)$ has been found in most cancer types; the only exception being pancreatic cancer, where the mutation frequency is approximately $20 \%$ (Hahn et al, 1996; Nagatake et al, 1996; Scutte et al, 1996; Takagi et al, 1996; Thiagalingham et al, 1996; Rozenblum et al, 1997).

In addition to loss of chromosomal material and intragenic mutations there is a third mechanism, DNA methylation, which may have important role in inactivation of tumour suppressor genes. Two types of DNA methylation changes appear to be connected with the progression of malignant tumours; hypomethylation induced activation of oncogenes and hypermethylation based silencing of tumour suppressor genes (Laird and Jaenish, 1994). Main targets of hypermethylation are normally unmethylated $\mathrm{CpG}$ islands locating in gene promoter regions. Methylation of cytosine at $\mathrm{CpG}$ dinucleotides of $5^{\prime} \mathrm{CpG}$ islands has been associated with transcriptional silencing of tumour suppressor genes in a variety of human cancers (Jones and Laird, 1999). For example, VHL gene promoter is commonly hypermethylated in renal cancers and RBI gene in retinoblastoma, respectively (Sakai et al, 1991; Herman et al, 1994).

In the present study, we examined whether hypermethylation of promoter could be an alternative mechanism to coding region mutations for SMAD4 inactivation. The $\mathrm{CpG}$ island near noncoding exon 1 was selected for this analysis (Figure 1), since it is well documented that methylation has important regulatory effects especially when involving these CpG rich areas (Bird, 1986). Twenty-six MSI and 16 MSS tumour and corresponding normal DNAs were selected for the analysis and no evidence of hypermethylation was found. The region analysed here contains many promotor associated structures. While we cannot exclude the existence of other relevant sequences, we consider the region analysed here as a likely candidate for the SMAD4 promoter. Six CCGG sites were available for methylation analysis by restriction. The possibility, that methylation of other $\mathrm{CpG}$ sites are important in silencing the SMAD4 gene cannot be excluded. Bearing these cautions in mind, our data suggests that the hypermethylation of the SMAD4 promoter region is not a key mechanism in SMAD4 inactivation.

In a recent study by Zhou et al (1999) two mutations were identified in the SMAD4 5'-untranslated region among the 6 endometrial tumours that had previously failed to express wild type SMAD4 (Zhou et al, 1999). In that study the mutation screening was focused on a $331 \mathrm{bp}$ long fragment, which spanned nucleotides -262 to +69 from the transcription start site. This fragment is part of the SMAD4 5'-untranslated region published by Minami et al (1998) and it contains several important transcription factor binding sites (Minami et al, 1998). To examine whether the region is mutated also in colorectal carcinomas, we sequenced this 
331-bp fragment from 15 MSS and seven MSI tumour samples and found no changes.

Miyaki et al (1999) analysed SMAD4 mutations from 176 colorectal tumours and found that SMAD4 mutation frequencies were $0 \%$ in adenoma, $10 \%$ in intramucosal carcinoma, $7 \%$ in primary invasive carcinoma without metastasis, $35 \%$ in primary invasive carcinoma with metastasis and $31 \%$ in distant metastasis. Thus, the frequency of SMAD4 mutations was correlating with the stage of colorectal cancer (Miyaki et al, 1999). Similar results were also published by Koyama et al (1999). They found somatic SMAD4 mutation in 7 of $64(11 \%)$ colorectal tumours of clinical stages II or III, all these tumours also showing LOH at $18 \mathrm{q} 21$. In the present study, 22 primary CRCs were selected into the SMAD4 mutation screening and the only change detected was a polymorphism in exon 2 (C11). According to the literature, SMAD4 polymorphisms are rare, so the frequency of this variant among Finnish control individuals was evaluated. In total, 84 controls were analysed and the change was found in one of them.

Our results suggest that SMAD4 is not frequently mutated in primary non-metastatic colorectal carcinoma and that the hypermethylation of the SMAD4 promoter region is not a key mechanism in colorectal tumorigenesis. As expression of SMAD4 appears to be decreased or lost in most colorectal cancers (Salovaara et al, submitted), further work is necessary to understand the molecular mechanisms of SMAD4 inactivation.

\section{ACKNOWLEDGEMENTS}

We would like to thank Emil Aaltonen Foundation, Sigrid Juselius Foundation, Finnish Cancer Society, the Academy of Finland, Finnish Cultural Foundation and Biocentrum Helsinki for supporting this work and Siv Lindroos for technical assistance.

\section{REFERENCES}

Aaltonen LA, Salovaara R, Kristo P, Canzian F, Hemminki A, Peltomäki P, Chadwick R, Kääriäinen H, Eskelinen M, Järvinen H, Mecklin J-P and de la Chapelle A (1998) Incidence of hereditary nonpolyposis colorectal cancer and the feasibility of molecular screening for the disease. N Eng J Med 338: 1481-1487

Bird AP (1986) CpG-rich islands and the function of DNA methylation. Nature 321 : 209-213

Cho KR, Oliner JD, Simons JW, Hedrick L, Fearon ER, Preisinger AC, Hedge P, Silverman GA and Vogelstein B (1994) The DCC gene: structural analysis and mutations in colorectal carcinomas. Genomics 19: 525-531

Eppert K, Scherer SW, Ozcelik H, Pirone R, Hoodless P, Kim H, Tsui LC, Bapat B, Gallinger S, Andrulis IL, Thomsen GH, Wrana JL and Attisano L (1996) MADR2 maps to 18q21 and encodes a TGFbeta-regulated MAD-related protein that is functionally mutated in colorectal carcinoma. Cell 86: 543-552

Fearon ER, Cho KR, Nigro JM, Kern SE, Simons JW, Ruppert JM, Hamilton SR, Preisinger AC, Thomas G, Kinzler KW and Vogelstein B (1990) Identification of a chromosome $18 \mathrm{q}$ gene that is altered in colorectal cancers. Science 247: 49-56

Hahn SA, Schutte M, Hoque AT, Moskaluk CA, da Costa LT, Rozenblum E, Weinstein CL, Fischer A, Yeo CJ, Hruban RH and Kern SE (1996) DPC4, a candidate tumor suppressor gene at human chromosome 18q21.1. Science 271: 350-353

Herman JG, Latif F, Weng Y, Lerman MI, Zbar B, Liu S, Samid D, Duan DS, Gnarra JR and Linehan WM (1994) Silencing of the VHL tumor suppressor gene by DNA methylation in renal carcinoma. Proc Natl Acac Sci USA 91: 9700-9704

Jones PA and Laird PW (1999) Cancer epigenetics comes of age. Nat Genet 21 163-167

Kikuchi-Yanoshita R, Konishi M, Fukunari H, Tanaka K and Miyaki M (1992) Loss of expression of the DCC gene during progression of colorectal carcinomas in familial adenomatous polyposis and non-familial adenomatous polyposis patients. Cancer Res 52: 3801-3803
Kinzler KW and Vogelstein B (1998) Colorectal tumours. In: The Genetic Basis of Human Cancer, Vogelstein B and Kinzler KW (eds) pp. 565-587. McGrawHill Press: United States

Korn WM, Yasutake T, Kuo WL, Warren RS, Collins C, Tomita M, Gray J and Waldman FM (1999) Chromosome arm 20q gains and other genomic alterations in colorectal cancer metastatic to liver, as analysed by comparative genomic hybridisation and fluorescence in situ hybridisation. Genes Chromosomes \& Cancer 25: 82-90

Koyama M, Ito M, Nagai H, Emi M and Moriyama Y (1999) Inactivation of both alleles of the DPC4/SMAD4 gene in advanced colorectal cancers: identification of seven novel somatic mutations in tumours from Japanese patients. Mutat Res 406: 71-77

Kuismanen SA, Holmberg MT, Salovaara R, Schweizer P, Aaltonen LA, de la Chapelle A, Nyström-Lahti M and Peltomäki P (1999) Epigenetic phenotypes distinguish microsatellite stable and -unstable colorectal cancers. Proc Natl Acac Sci USA 96: 12661-12666

Laird PW and Jaenisch R (1994) DNA methylation and cancer. Hum Molec Genet 3 : 1487-1495

MacGrogan D, Pegram M, Slamon D and Bookstein R (1997) Comparative mutational analysis of DPC4 (SMAD4) in prostatic and colorectal carcinomas. Ongogene 15: 1111-1114

Meijer GA, Hermsen MA, Baak JP, van Diest PJ, Meuwissen SG, Belien JA, Hoovers JM, Joenje H, Snijders PJ and Walboomers JM (1998) Progression from colorectal adenoma to carcinoma is associated with non-random chromosomal gains as detected by comparative genomic hybridisation. J Clin Pathol 51: 901-909

Minami R, Kitazawa R, Maeda S and Kitazawa S (1998) Analysis of 5'-flanking region of human Smad4 (DPC4) gene. Biochimica et Biophysica Acta 1443: 182-185

Miyaki M, Iijima T, Konishi M, Sakai K, Ishii A, Yasuno M, Hishima T, Koike M, Shitara N, Iwama T, Utsunomiya J, Kuroki T and Mori T (1999) Higher frequency of Smad4 gene mutation in human colorectal cancer with distant metastasis. Oncogene 20: 3098-3103

Nagatake M, Takagi Y, Osada H, Uchida K, Mitsudomi T, Saji S, Shimokata K and Takahashi T (1996) Somatic in vivo alterations of the DPC4 gene at 18q21 in human lung cancers. Cancer Res 56: 2718-2720

Ried T, Knutzen R, Steinbeck R, Blegen H, Schrock E, Heselmeyer K, du Manoir S and Auer G (1996) Comparative genomic hybridisation reveals a specific pattern of chromosomal gains and losses during the genesis of colorectal tumors. Genes Chromosomes Cancer 15: 234-245

Roth S, Sistonen P, Hemminki A, Salovaara R, Loukola A, Avizienyte E, Lynch P, Amos C, Mecklin J-P, Kellokumpu I, Järvinen H and Aaltonen LA (1999) SMAD genes in juvenile polyposis. Genes Chromosomes Cancer 26: 54-61

Rozenblum E, Schutte M, Goggins M, Hahn SA, Panzer S, Zahurak M, Goodman SN, Sohn TA, Hruban RH, Yeo CJ and Kern SE (1997) Tumour suppressive pathways in pancreatic carcinoma. Cancer Res 57: 1731-1734

Sakai T, Toguchida J, Ohtani N, Yandell DW, Rapaport JM and Dryja TP (1991) Allele-specific hypermethylation of the retinoblastoma tumour suppressor gene. Am J Hum Genet 48: 880-888

Salovaara R, Loukola A, Kristo P, Kääriäinen H, Ahtola H, Eskelinen M, Härkönen N, Julkunen R, Kangas E, Ojala S, Tulikoura J, Valkamo E, Järvinen H, Mecklin J-P, Aaltonen LA and de la Chapelle A (2000) Population-wide molecular detection of hereditary nonpolyposis colorectal cancer. J Clin Oncol 18: 2193-2200

Schutte M, Hruban RH, Hedrick L, Cho KR, Nadasdy GM, Weinstein CL, Bova GS, Isaacs WB, Cairns P, Nawroz H, Sidransky D Jr, Casero RA, Meltzer PS, Hahn SA and Kern SE (1996) DPC4 gene in various tumour types. Cancer Res 56 $2527-2530$

Takagi Y, Kohmura H, Futamura M, Kida H, Tanemura H, Shimokawa K and Saji S (1996) Somatic alterations of the DPC4 gene in human colorectal cancers in vivo. Gastroenterology 111: 1369-1372

Thiagalingam S, Lengauer C, Leach FS, Schutte M, Hahn SA, Overhauser J, Willson JK, Markowitz S, Hamilton SR, Kern SE, Kinzler KW and Vogelstein B (1996) Evaluation of candidate tumour suppressor genes on chromosome 18 in colorectal cancers. Nat Genet 13: 343-346

Toyota M, Ahuja N, Ohe-Toyota M, Herman JG, Baylin SB and Issa J-P (1999) CpG island metylator phenotype in colorectal cancer. Proc Natl Acac Sci USA 96 8681-8686

Vogelstein B, Fearon ER, Hamilton SR, Kern SE, Preisinger AC, Leppert M, Nakamura Y, White R, Smits AM and Bos JL (1988) Genetic alterations during colorectal tumour development. N Engl J Med 319: 525-532

Wilentz RE, Su GH, Dai JL, Sparks AB, Argani P, Sohn TA, Yeo CJ, Kern SE and Hruban RH (2000) Immunohistochemical labeling for Dpc4 Mirrors genetic status in pancreatic adenocarcinoma. Am J Pathol 156: 37-43

Zhou Y, Kato H, Shan D, Minami R, Kitazawa S, Matsuda T, Arima T, Barrett JC and Wake N (1999) Involvement of mutations in the DPC4 promoter in endometrial carcinoma development. Mol Carcinog 25: 64-72 